\title{
NUTRITIONAL VALUES AND METABOLIC PROFILE WITH AND WITHOUT BOILED TREATMENT OF 'GALLO MATESE' BEANS (PHASEOLUS VULGARIS L.), A LANDRACE FROM SOUTHERN ITALY
}

\author{
Nicola Landi, Sara Ragucci, Michelina Fiorentino, Vincenzo Guida, Antimo Di Maro $\bowtie$ \\ Department of Environmental, Biological and Pharmaceutical Sciences and Technologies (DiSTABiF), University of Campania \\ 'Luigi Vanvitelli' \\ Via Vivaldi 43, I-81100 Caserta, Italy
}

\begin{abstract}
Background. 'Gallo Matese' beans are known as a typical legume of Southern Italy and continue to be consumed as a traditional food preserving the diversity of this region. Nonetheless, no information about the nutritional values of this legume is available. The objective of the present investigation was to determine the nutritional value and metabolic profile of 'Gallo Matese' beans.

Results. 'Gallo Matese' beans contain high levels of proteins $(22.64 \mathrm{~g} / 100 \mathrm{~g})$ and essential amino acids $(8.3 \mathrm{~g} / 100 \mathrm{~g})$. Furthermore, different unsaturated fatty acids contribute to the total amount of lipids $(0.97 \mathrm{~g} / 100 \mathrm{~g})$; among them, the essential PUFA $\alpha$-linolenic $(0.48 \mathrm{~g} / 100 \mathrm{~g})$ and linoleic $(0.39 \mathrm{~g} / 100 \mathrm{~g})$ acids are the most abundant. The total phenol content was revealed and ABTS and ORAC-fluorescein methods were applied to determine the radical scavenging capabilities of the extract with and without boiled treatment. Finally, a decrease in trypsin and chymotrypsin inhibitory activities was estimated before and after the boiling procedure. Conclusion. The data obtained show that 'Gallo Matese' beans are a functional food with healthy qualities. Overall, these results are useful to promote their cultivation and consumption, thus preserving Italian beans biodiversity due to consumer interest in choosing a healthy diet, such as the Mediterranean diet.
\end{abstract}

Keywords: amino acids, antioxidants, fatty acids, legumes, food quality

\section{INTRODUCTION}

The Fabaceae or Leguminosae, commonly known as the Legume family, are flowering plants intensively cultivated for the production of their grain seed, called pulse, which is a rich source of vegetable proteins, dietary fibers, carbohydrates, vitamins and dietary minerals (Mudryj et al., 2014). These seeds are important not only in both economical and nutritional terms, but also for biological nitrogen fixation (Nulik et al., 2013).

The most popular seeds of Leguminosae are soya, pea, lentil and broad or common beans; whose consumption is significantly increased due to a vegetarian

\footnotetext{
* This study was supported by funds from the University of Campania 'Luigi Vanvitelli'. This study was made possible by the care and abnegation of all participants, despite the absence of dedicated funds and chronic difficulties afflicting the Italian scientific community.
}

凶antimo.dimaro@unicampania.it 
lifestyle, as legumes offer a healthy alternative to meat proteins (Nelson et al., 2016). In fact, although legumes are low in sulphur-containing amino acids, their usual combination with other sources such as cereals, roots and tubers, provides great protein quality (Iqbal et al., 2006). Furthermore, pulses are beneficial because of their low glycemic index (Jenkins et al., 2012) and their consumption has a positive effect on several other cardiovascular disease risk factors, such as blood pressure, platelet activity, and inflammation (Bazzano et al., 2001). In addition, many phytochemicals found in legumes possess antioxidant (Amarowicz and Pegg, 2008) and anti-carcinogenic (Mudryj et al., 2014) qualities.

Common bean seeds of Phaseolus vulgaris L., are the most consumed legume crops, second to soya beans in global legume seed cultivation (Nedumaran et al., 2015). The plant of $P$. vulgaris and therefore its seeds, known at least seven thousand years ago in the Americas, were probably introduced to Europe from Mesoamerica (Zeven, 1997). After its importation, the common bean spread over the European continent through specific agronomic characteristics such as: 1) cultivation in the warm season that does not tolerate long cold periods; 2) moderate rainfall, particular essential during and immediately after the flowering stage; 3) not sensitive to soil type, as long as it is reasonably fertile (Katungi et al., 2009). On the other hand, the consumption of common beans, along with maize, potato, pumpkin and pears from the Americas, was one of the causes of the demographic increase registered in Europe between the seventeenth and eighteenth centuries (Lee, 1982). The seeds of $P$. vulgaris were probably introduced to Italian territory from Spain and over time spread in an extensive manner (Piergiovanni and Lioi, 2010). The peculiar pedoclimatic characteristics of Italian territory, such as soil type, climatic condition or geographical isolation produced a myriad of landraces (Comes, 1910). This process, made easier because of selective pressure exerted by Italian farmers motivated by aesthetic and organoleptic preferences, led to the emergence of about five hundred species in Italy (Piergiovanni and Lioi, 2010). Nowadays, the nutritional and health benefits of common bean consumption in Italian and Mediterranean countries have made this legume one of the key foods in the Mediterranean diet (Widmer et al., 2015).
In particular, in the Campania region more than twenty different types of beans are known as traditional regional foods (Gazzetta_Ufficiale, 2016; Piergiovanni et al., 2015; Scarano et al., 2014) and some of them, such as 'Occhio nero di Oliveto Citra' (Zaccardelli et al., 2013) or 'Controne' beans (Del Piano et al., 2012; Mennella et al., 2003) are the subject of study.

Within this framework, our group aims to investigate the biochemical and nutritional properties of autochthonous beans of Campania region in order to promote their consumption at local and international levels, and has decided to characterize 'Gallo Matese' beans in the way already done for other typical cultivars (Dosi et al., 2013; Landi et al., 2015; Pacifico et al., 2014; Tamburino et al., 2012a). These dry legumes, produced in low quantities through family cultivation, are high-quality beans and are mainly sold in the local market. 'Gallo Matese' beans take their name from Gallo Matese, a small town located near Caserta in the Matese Mountain chain. They are a local ecotype with ocher-colored pods, a small size and white flowers. The plants, one meter high, with indeterminate growth, have a climbing habit and traditionally grow on local red wheat. The seeds are white and small with a hilar scar, thin skin, delicate flavour, high digestibility and a shape that visually resembles a kidney,

In this framework, macronutrient content as well as total and free amino acids and fatty acids were determined. Furthermore, the antioxidant capability of raw and boiled 'Gallo Matese' beans was estimated in terms of total phenol content, ORAC value and ABTS radical scavenging activity. Finally, due to common beans being known to contain anti-nutritional factors such as trypsin and chymotrypsin inhibitors, they were analysed with and without boiling.

\section{MATERIAL AND METHODS}

\section{Chemicals and reagents}

2,2'-azobis-(2-amidinopropane)-dihydrochloride (AAPH), nor-leucine (nor-Leu), fluorescein, Folin-Ciocalteau reagent, gallic acid, salts and 6-hydroxy-2,5,7,8-tetramethylchroman-2-carboxylic acid $\left(\operatorname{Trolox}^{\circledR}\right)$ were purchased from Sigma-Aldrich (Milan, Italy). Solvents were from Sigma-Aldrich. Chemicals and solvents for the Kjeldahl method were from Carlo Erba Reagents (Milan, Italy), whereas those for 
automated amino acid analysis were provided from Biochrom (Cambridge, U.K.).

\section{Material and sampling of 'Gallo Matese' bean seeds}

P. vulgaris seeds were grown in typical soil and illumination conditions in Gallo Matese, $\sim 70 \mathrm{~km}$ north-west of Caserta, Italy (geographical coordinates: $41^{\circ} 28^{\prime} \mathrm{N}$ $14^{\circ} 13^{\prime} \mathrm{E}$ ). Bean seeds manually and randomly harvested across the reference field in 2016, and collected in two different territory of Gallo Matese, were then sun-dried for some weeks. Dried bean seeds were powdered with the Cyclone Sample Mill Instrument (PBI International, Milan, Italy), until flour of a homogeneous size was obtained. The material, hereafter "seed flour", was stored at a temperature of $-20^{\circ} \mathrm{C}$ in plastic bags and in the dark. All measurements were performed in triplicate.

\section{Ash and moisture content}

The ash content and moisture level were determined according to the AOAC official method (AOAC, 1997).

\section{Macronutrient content}

Total raw protein (AOAC, 1997), lipid (by using Soxhlet apparatus using $\mathrm{CHCl}_{3}$ as extracting solvent) and carbohydrate (FAO, 2003) content was determined as previously reported (Landi et al., 2017; Landi et al., 2015).

\section{Amino acid composition}

For the analysis of free amino acid composition, three aliquots of seed flour $(\sim 200 \mathrm{mg})$ were precipitated with $80 \%$ cold ethanol $(1.0 \mathrm{~mL})$, in the presence of $n o r$-Leu $(50.0 \mathrm{nmol})$ as an internal standard, homogenized with a teflon pestle and centrifuged at 14000 $\times \mathrm{g}$, at $4^{\circ} \mathrm{C}$. The supernatants were lyophilized, treated with $3 \%$ sulfosalicylic acid $(500 \mu \mathrm{L})$ to precipitate any protein fraction still present, and centrifuged again (Iriti et al., 2009). For the analysis of total (free and protein) amino acids, $\sim 10 \mathrm{mg}$ of seeds flour were hydrolysed with $0.5 \mathrm{~mL}$ of $6 \mathrm{~N} \mathrm{HCl}$ containing $0.05 \%$ thioglycolic acid and nor-Leu as an internal standard at $110^{\circ} \mathrm{C}$ for $20 \mathrm{~h}$ and treated as previously reported (Ferrara et al., 2011). Aliquots of hydrolysed and nonhydrolysed samples were directly analysed by using a Biochrom30 amino acid analyser (Biochrom, Cambridge, U.K.).

\section{Evaluation of the antioxidant capacity of 'Gallo Matese' beans}

The total phenol content (TPC) and antioxidant capability of seed flour were measured on acetone/water extracts previously obtained through maceration. For this purpose three replicate seed flour samples $(\sim 200 \mathrm{mg})$ were extracted in $5 \mathrm{~mL}$ of acetone/water $(80: 20, \mathrm{v} / \mathrm{v})$ for $3 \mathrm{~h}$ in a rotary shaker. After this period, the samples were centrifuged at $10000 \mathrm{~g}$ for $30 \mathrm{~min}$. The supernatant was filtered through a $0.22 \mu \mathrm{m}$ PVDF filter (Anton et al., 2009). The extract was stored at $-20^{\circ} \mathrm{C}$ until use. Furthermore, in order to evaluate the effect of boiling (the most commonly used cooking method for common beans) on phenol content and antioxidant capacity, three replicate samples $(5.0 \mathrm{~g}$ each) of raw material were first boiled in water $(50 \mathrm{~mL}$, each). After $120 \mathrm{~min}$, the cooked beans and the cooking water were freezedried. The samples obtained were extracted as described above. Folin-Ciocalteau, $\mathrm{ABTS}^{+}$and ORAC assays were carried out by performing three replicate measurements for three samples $(n=3)$ of each extract. The activities recorded were compared to a blank.

\section{Total phenol content determination}

The total phenol amount of seed flour was determined according to the Folin-Ciocalteau procedure on aliquots of extracts in acetone/waters. The content of the TPC value of the samples was expressed as mg gallic acid equivalents (GAE) per $100 \mathrm{~g}$ of seed flour.

\section{Determination of ABTS radical cation scavenging capacity}

The $\mathrm{ABTS}^{++}$solution scavenging capacity of seed flour was estimated as previously reported (Tamburino et al., 2012a). The results were expressed in terms of TEAC values ( $\mu \mathrm{mol}$ Trolox ${ }^{\circledR}$ Equivalents per $100 \mathrm{~g}$ of seed flour).

\section{Oxygen radical absorbance capacity assay (ORAC)}

The antioxidant potential of seed flour was measured by Oxygen Radical Absorbance capacity (ORAC) assay as previously reported (Landi et al., 2015; Landi et al., 2017). The analysis was performed using 96-well microplates in which $25 \mu \mathrm{L}$ of appropriately 
diluted acetone/water extract from raw, cooked common beans with and without cooking water. The antioxidant activity (ORAC value) was calculated by using the Trolox ${ }^{\circledR}$ calibration curve. The ORAC value was expressed as Trolox ${ }^{\circledR}$ equivalents $(\mu \mathrm{mol}$ Trolox per $100 \mathrm{~g}$ of seed flour).

\section{Determination of trypsin and chymotrypsin inhibitory activities}

Three replicate samples of seed flour $(1.0 \mathrm{~g}$ each) were extracted overnight under magnetic stirring at $4^{\circ} \mathrm{C}$ in $80 \mathrm{mM}$ Tris ${ }^{\bullet} \mathrm{Cl}, \mathrm{pH} 7.8$, containing $0.1 \mathrm{M} \mathrm{CaCl}_{2}$ $(1: 4 ; \mathrm{w} / \mathrm{v})$. The reaction mixtures were centrifuged at $24000 \mathrm{~g}$ (Centrifuge Avant J-25, Beckman Coulter, CA, USA) at $4^{\circ} \mathrm{C}$ for $60 \mathrm{~min}$. The supernatants were first filtered on Miracloth (pore size: 22-25 $\mu \mathrm{m}$ ) and then freeze-dried.

The protein concentration was determined with the Bio-Rad Protein Assay kit following the manufacturer's instructions and using bovine serum albumin (BSA) as standard.

Trypsin and anti-trypsin activities, as well as chymotrypsin and anti-chymotrypsin activities, were determined following a procedure already described (Tamburino et al., 2012b), using TAME ( $p$-toluenesulfonyl-L-arginine methyl ester) and BTEE (N-benzoyl-L-Tyrosine ethyl ester) as substrates, respectively. One inhibitory unit is defined as the amount of inhibitor that, yields a $30 \%$ decrease in the assayed enzymatic activity under assay conditions. An increasing concentration of seed protein extract was added to a fixed concentration of enzyme, which in our conditions corresponded to 0.05 absorbance/min monitoring for $5 \mathrm{~min}$ of the reaction. Residual enzyme activities are expressed as a percentage of the control samples (enzyme activity in the absence of protein extract). The $\mathrm{IC}_{50}$ values of trypsin and $\alpha$-chymotrypsin activities (i.e. the half maximal inhibitory concentration) of bean protein extract were calculated as previously reported (Tamburino et al., 2012b).

\section{Gas chromatographic analysis of fatty acid methyl esters}

The analysis of fatty acid methyl ester content was performed as previously reported (Ferrara et al., 2011). The fatty acid methyl esters were identified by comparing their retention times with those of standard fatty acid methyl esters (Grain Fatty Acid Methyl Ester mix 47801, Supelco).

\section{Free glucose content}

To determine the glucose level, three aliquots of seeds flour $(\sim 30 \mathrm{mg})$ were extract as previously reported (Bailly et al., 2001). The dry extracts were dissolved in $100 \mu \mathrm{L}$ of milliQ water. The samples $(20 \mu \mathrm{L})$ were assayed according to the Glucose LR procedure kit, an enzymatic colorimetric method, following the manufacture's instruction (Glucose LR, SGM Italia, Rome, Italy).

\section{Statistical analysis}

The analyses were repeated three times for each sample; the mean and standard deviation (SD) of experimental values were reported. Data analysis was carried out with Excel Office 2010 (Microsoft Corporation, Redmond, WA, USA). The $\mathrm{IC}_{50}$ values were calculated based on inhibition curves by plotting the residual enzyme activities versus different concentrations of protein extract by fitting data with a non-linear regression analysis on a semi-logarithm scale by using the GraphPad Prism 5 software (GraphPad software Inc., California, USA). All measurements were performed in triplicate and the results are reported as mean $\pm \mathrm{SD}$ values. The Bonferroni post-test was used to determine significant differences between 'Gallo Matese' bean seeds collected at two different sites, named $\mathrm{C} 1$ and $\mathrm{C} 2$. The test was performed using a $P<0.05$.

\section{RESULTS AND DISCUSSION}

\section{Nutritional values}

In order to promote 'Gallo Matese' beans, autochthonous beans of the Campania Region, a thorough investigation of their biochemical and nutritional properties was carried out following a workflow reported in Figure 1.

The nutritional values of dried bean seeds from Gallo Matese (hereafter 'Gallo Matese' beans) obtained by analysis of two different sites (named $\mathrm{C} 1$ and C2) and their average ( $\bar{x})$ are reported in Table 1. On the other hand, since the statistical analysis did not produce significant differences, the average values were compared with those of 'Cannellini' and 'Borlotti' beans, the most known Italian landraces 


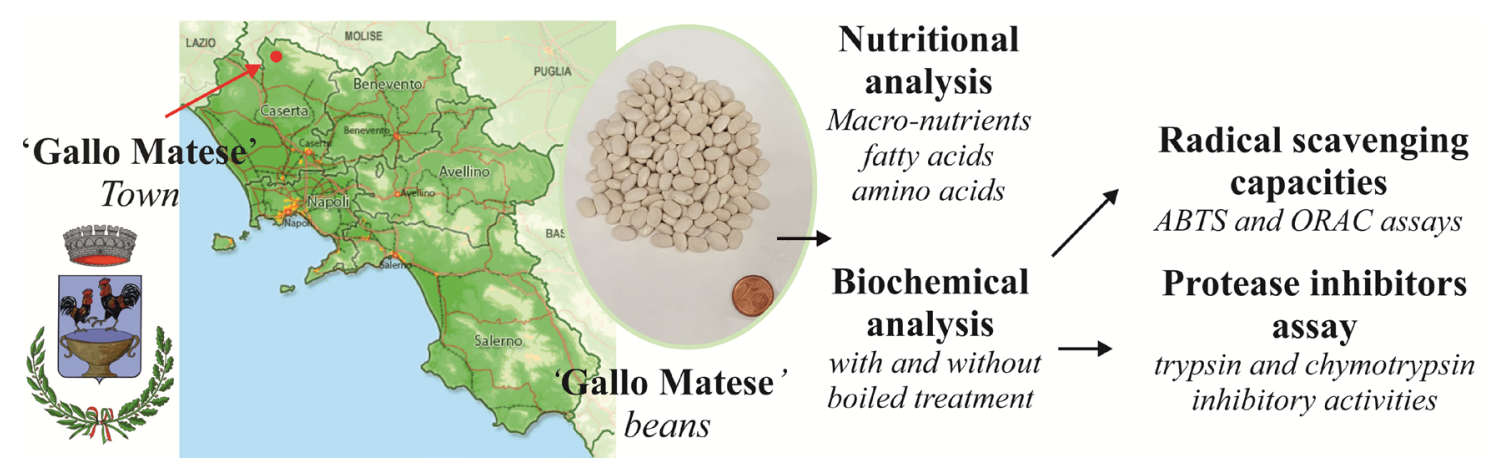

Fig. 1. Schematic workflow of the experimental strategy for the biochemical and nutritional characterization of 'Gallo Matese' beans

(Piergiovanni and Lioi, 2010), whose values are reported by the "Centro di Ricerca per gli Alimenti e la Nutrizione" (CREA, 2009).

The crude protein content of different types of beans represents between $16 \%$ and $33 \%$ of seeds (Azarpazhooh and Boye, 2012). In this study, the average amount of crude protein from "Gallo Matese" beans $(22.64 \mathrm{~g} / 100 \mathrm{~g})$ was about $3 \%$ lower than 'Cannellini' beans $(23.40 \mathrm{~g} / 100 \mathrm{~g})$ and about $12 \%$ higher than 'Borlotti' beans $(20.20 \mathrm{~g} / 100 \mathrm{~g})$. Furthermore, the crude protein content of 'Gallo Matese' beans is similar to 'Fagiolo occhio nero di Oliveto Citra' beans $(22.84 \mathrm{~g} / 100 \mathrm{~g})$ (Zaccardelli et al., 2013) and slightly different with respect to several Campania bean landraces as 'Dente di morto', 'Fagiolo di Controne', Mustacciello di Villaricca', which have a crude mean protein content in a range between 20.70 and 25.85 $\mathrm{g} / 100 \mathrm{~g}$ (Piergiovanni et al., 2015).

Lipid content $(2.45 \mathrm{~g} / 100 \mathrm{~g})$ was higher than that reported for both 'Cannellini' $(1.60 \mathrm{~g} / 100 \mathrm{~g})$ and 'Borlotti' $(2.20 \mathrm{~g} / 100 \mathrm{~g})$, while in the literature data about Campania landraces are not available. In general, the amount retrieved is in accordance with the range (1.0$3.0 \%$ ) of common beans (Azarpazhooh and Boye, 2012), confirming that dry beans are a low source of lipids.

Table 1. Nutritional values of 'Gallo Matese' and Italian common beans (CREA, 2009)

\begin{tabular}{lccccc}
\hline & \multicolumn{3}{c}{ 'Gallo Matese' beans, $\mathrm{g} / 100 \mathrm{~g}$} & \multicolumn{2}{c}{ Italian common beans, $\mathrm{g} / 100 \mathrm{~g}$} \\
\cline { 2 - 5 } & $\mathrm{C}_{1}$ & $\mathrm{C}_{2}$ & $\overline{\mathrm{x}}$ & Cannellini & Borlotti \\
\hline Proteins & $23.08 \pm 1.80$ & $22.19 \pm 1.70$ & 22.64 & 23.4 & 20.2 \\
Lipids & $2.49 \pm 0.54$ & $2.40 \pm 0.34$ & 2.50 & 1.6 & 2.2 \\
Ash & $4.31 \pm 0.03$ & $4.24 \pm 0.04$ & 4.80 & n.r. & n.r. \\
Moisture & $9.76 \pm 0.50$ & $9.14 \pm 0.32$ & 9.45 & 10.0 & 10.3 \\
Starch & $55.43 \pm 5.50$ & $55.58 \pm 6.00$ & 55.51 & 38.7 & 40.0 \\
Glucose, $\mathrm{mg} / 100 \mathrm{~g}$ & $66.44 \pm 3.33$ & $76.68 \pm 4.67$ & 71.56 & n.r. & n.r. \\
Carbohydrates & 60.36 & 62.03 & 61.21 & 65.0 & 47.5 \\
\hline
\end{tabular}

Values are means $( \pm \mathrm{SD})$ of triplicate analyses $(n=3)$ and are expressed on a dry-weight basis.

Data in the same row are not significantly different $(P>0.05)$ using the Bonferroni post-test.

n.r. - not reported. 
Carbohydrate content is $61.21 \%$ [range 55.0 65.0\% (Azarpazhooh and Boye, 2012)], slightly lower than that reported for 'Cannellini' beans (about 6\%), but higher with respect to 'Borlotti' beans (about 22\%).

In addition, as reported in Table 1, the starch and free glucose content were determined. In particular, the starch content of 'Gallo Matese' beans (55.51 $\mathrm{g} / 100 \mathrm{~g}$ ) was higher than that reported for both 'Cannellini' (38.70 g/100 g) and 'Borlotti' (40.00 g/100 g). Considering the mean value of starch between $44.4 \%$ and $47.8 \%$ (Azarpazhooh and Boye, 2012) in common beans, 'Gallo Matese' beans have a higher content of this carbohydrate, although this may be influenced by the environmental conditions in which the plant grows and in which seed maturation occurs. Finally, the free glucose level of 'Gallo Matese' beans was 71.56 $\mathrm{mg} / 100 \mathrm{~g}$.

\section{Amino acid content}

Total amino acid content (free plus protein) from hydrolysate 'Gallo Matese' beans obtained by analysis of both $\mathrm{C} 1$ and $\mathrm{C} 2$ sites and their average $(\overline{\mathrm{x}})$ is reported in Table 2, and no statistical differences were noted. Subsequently, the average values $(\overline{\mathrm{x}})$ were compared with those of both 'Cannellini' and 'Borlotti' beans, showing qualitative and quantitative differences.

Glx (glutamic acid + glutamine; $3.42 \mathrm{~g} / 100 \mathrm{~g}$ ) was the most abundant among the total amino acids in 'Gallo Matese' beans, followed by arginine $(1.76 \mathrm{~g} / 100 \mathrm{~g})$, Asx (aspartic acid + asparagine; $1.65 \mathrm{~g} / 100 \mathrm{~g}$ ), proline $(1.51 \mathrm{~g} / 100 \mathrm{~g})$, phenylalanine $(1.49 \mathrm{~g} / 100 \mathrm{~g})$ and serine $(1.39 \mathrm{~g} / 100 \mathrm{~g})$, which represented about $53.1 \%$ of the total amino acids. In addition, the amount of essential amino acids [His, Ile, Leu, Lys, Met, Phe, Thr, Val; Trp (tryptophan is not included as it was not determined in the total hydrolysed samples - see Table 2)] in 'Gallo Matese' beans was $8.25 \mathrm{~g} / 100 \mathrm{~g}$ ( $\sim 39.0 \%$ of total). The amount of methionine and cysteine (as cysteine and cysteic acid) in 'Gallo Matese' beans is $0.86 \mathrm{~g} / 100 \mathrm{~g}$ ( $\sim .0 \%$ of total), confirming the low level of sulphur amino acids as reported for other legumes. On the other hand, the amount of sulphur amino acids in 'Cannellini' and 'Borlotti' beans is $0.45 \mathrm{~g} / 100 \mathrm{~g}(2.08 \%$ of total) and $0.40 \mathrm{~g} / 100 \mathrm{~g}(2.07 \%$ of total), respectively.

On the other hand, three Italian landraces revealed large amounts of the same amino acid, glutamic acid, which is $16.20 \%, 17.17 \%$ and $16.40 \%$ for 'Gallo
Matese', 'Cannellini' and 'Borlotti' beans, respectively. These data are similar to those reported by Neacsu et al. (2016), where common beans had a glutamic acid level of $16.31 \%$. Furthermore, phenylalanine, threonine, arginine, proline, serine, and tyrosine in 'Gallo Matese' beans were higher than 'Cannellini', 'Borlotti' and data reported by Neacsu (2016). In terms of free amino acids, the total amount in 'Gallo Matese' beans was 388.39 $\mathrm{mg} / 100 \mathrm{~g}$ on a dry-weight basis (Table 3). Glutamine was by far the most abundant among free protein amino acids (about $27.36 \%$ of total). Furthermore, aspartic acid $(97.13 \mathrm{mg} / 100 \mathrm{~g})$, asparagine $(52.91 \mathrm{mg} / 100 \mathrm{~g})$ and arginine $(36.20 \mathrm{mg} / 100 \mathrm{~g})$ were the most abundant free amino acids in 'Gallo Matese' beans, whereas the amount of each of the other protein amino acids did not exceed $95.86 \mathrm{mg} / 100 \mathrm{~g}$ of product $(24.68 \%$ of free amino acids total content). The analysis also evidenced the presence of eleven non-protein amino acids [i.e. $\mathrm{L}-\alpha$-aminoadipic acid (AAAA); L- $\alpha$-amminobutirrico (AABA); b-alanine (b-Ala); L-citrulline (Citr), L-cystathionine (Cysth); ethanolamine (Ethan); g-amino-n-butyric acid (GABA); phosphorylethanolamine (Pea); phosphoserine (Phser); L-sarcosine (Sarc); taurine (Taur)]. The amount of these non-protein amino acids was $20.09 \mathrm{mg} / 100 \mathrm{~g}$ (5.17\% of total). The free amino acid content of 'Cannellini' and 'Borlotti' beans (retrieved in INRAN databank) and other landraces has not been published previously.

However, statistical analysis shows that significant differences between $\mathrm{C} 1$ and $\mathrm{C} 2$ samples are only present for asparagine or glutamine amino acids, which is most likely due to pedoclimatic differences between two sites and, in particular, nitrogen availability (Postles et al., 2016).

\section{Fatty acid composition analysis}

Common beans have a low total lipid content mainly comprising unsaturated fatty acids with a high percentage of both linoleic (C18:2, n-6) and linolenic (C18:3, n-3) fatty acids (Oomah et al., 2011).

The total saturated, monounsaturated and polyunsaturated fatty acid contents of 'Gallo Matese' beans, obtained by analyses of both $\mathrm{C} 1$ and $\mathrm{C} 2$ sites and their average $(\overline{\mathrm{x}})$, are reported in Table 4 . However, since the statistical analysis did not reveal significant differences, the average values were compared with those of three different varieties of Slovenian common beans, 
Landi, N., Ragucci, S., Fiorentino, M., Guida, V., Di Maro, A. (2017). Nutritional values and metabolic profile with and without boiled treatment of 'Gallo Matese' beans (Phaseolus vulgaris L.), a landrace from Southern Italy. Acta Sci. Pol. Technol. Aliment., 16(3), 331-344. http://dx.doi.org/10.17306/J.AFS.2017.0510

Table 2. Total amino acid composition of 'Gallo Matese' and Italian common beans (CREA, 2009)

\begin{tabular}{|c|c|c|c|c|c|}
\hline \multirow{2}{*}{ Amino acid } & \multicolumn{5}{|c|}{ 'Gallo Matese' beans, g/100 g - Italian common beans, g/100 g } \\
\hline & $\mathrm{C}_{1}$ & $\mathrm{C}_{2}$ & $\overline{\mathrm{x}}$ & Cannellini & Borlotti \\
\hline \multicolumn{6}{|c|}{ Essential amino acids } \\
\hline His & $0.77 \pm 0.07$ & $0.67 \pm 0.04$ & 0.72 & 0.66 & 0.60 \\
\hline Ile & $0.89 \pm 0.08$ & $0.75 \pm 0.02$ & 0.82 & 1.24 & 1.07 \\
\hline Leu & $1.47 \pm 0.14$ & $1.13 \pm 0.05$ & 1.30 & 0.72 & 1.63 \\
\hline Lys & $1.45 \pm 0.16$ & $1.14 \pm 0.05$ & 1.30 & 1.64 & 1.44 \\
\hline Met & $0.38 \pm 0.07$ & $0.31 \pm 0.02$ & 0.35 & 0.25 & 0.20 \\
\hline Phe & $1.58 \pm 0.12$ & $1.39 \pm 0.04$ & 1.49 & 1.34 & 1.15 \\
\hline Thr & $1.29 \pm 0.13$ & $1.11 \pm 0.03$ & 1.20 & 0.92 & 0.80 \\
\hline Trp & n.d. & n.d. & - & 0.22 & 0.20 \\
\hline Val & $1.15 \pm 0.11$ & $0.98 \pm 0.03$ & 1.07 & 1.38 & 1.07 \\
\hline \multicolumn{6}{|c|}{ Non-essential amino acids } \\
\hline Ala & $1.04 \pm 0.11$ & $0.84 \pm 0.03$ & 0.94 & 0.98 & 0.86 \\
\hline Arg & $1.98 \pm 0.34$ & $1.53 \pm 0.02$ & 1.76 & 1.52 & 1.17 \\
\hline Asx & $1.80 \pm 0.17$ & $1.50 \pm 0.05$ & 1.65 & 2.85 & 2.40 \\
\hline Cys & $0.02 \pm 0.00$ & $0.03 \pm 0.00$ & 0.03 & 0.20 & 0.20 \\
\hline Cysteic acid & $0.48 \pm 0.04$ & $0.48 \pm 0.01$ & 0.48 & - & - \\
\hline Glx & $3.80 \pm 0.41$ & $3.03 \pm 0.12$ & 3.42 & 3.71 & 3.17 \\
\hline Gly & $0.87 \pm 0.09$ & $0.69 \pm 0.03$ & 0.78 & 0.94 & 0.77 \\
\hline Pro & $1.87 \pm 0.04$ & $1.15 \pm 0.08$ & 1.51 & 0.96 & 0.75 \\
\hline Ser & $1.52 \pm 0.14$ & $1.25 \pm 0.05$ & 1.39 & 1.36 & 1.20 \\
\hline Tyr & $0.95 \pm 0.09$ & $0.86 \pm 0.03$ & 0.91 & 0.72 & 0.65 \\
\hline Total & 23.31 & 18.84 & 21.08 & 21.61 & 19.33 \\
\hline
\end{tabular}

Values are means $( \pm \mathrm{SD})$ of triplicate analyses $(n=3)$ and are expressed on a dry-weight basis.

Data in the same row are not significantly different $(P>0.05)$ using a Bonferroni post-test.

Protein amino acids. A three-letter code has been used: Asx - L-asparagine + L-aspartic acid, Arg - L-arginine, Cys - L-half cystine, Glx - L-glutamine + L-glutamic acid, Gly - glycine, His - L-histidine, Ile - L-isoleucine, Leu - L-leucine, Lys - L-lysine, Met - L-methionine, Phe - L-phenylalanine, Pro - L-proline, Ser - L-serine, Thr - L-threonine, Trp - L-tryptophan, Tyr - L-tyrosine, Val - L-valine.

n.d. - not determined.

Češnjevec, Semenarna_22 and Cipro beans (Pirman and Stibilj, 2003), given the absence of data in Italian "Centro di Ricerca per gli Alimenti e la Nutrizione" (CREA, 2009). The quantitative analysis of fatty acids by using GC/MS revealed that 'Gallo Matese' beans are relatively low in lipids, with a saturated fatty acid content of only $19.7 \%(238 \mathrm{mg} / 100 \mathrm{~g})$ and mainly consisting of unsaturated fatty acids. 'Gallo Matese' 
Table 3. Free amino acid composition of 'Gallo Matese' beans

\begin{tabular}{cccc}
\hline \multirow{2}{*}{ Amino acid } & \multicolumn{3}{c}{ 'Gallo Matese' beans, $\mathrm{mg} / 100 \mathrm{~g}$} \\
\cline { 2 - 3 } & $\mathrm{C}_{1}$ & $\mathrm{C}_{2}$ & $\overline{\mathrm{x}}$ \\
\hline
\end{tabular}

Essential amino acids

$\begin{array}{lrrr}\text { His } & 9.38 \pm 0.68 & 5.48 \pm 0.02 & 7.43 \\ \text { Ile } & 2.17 \pm 0.10 & 1.15 \pm 0.15 & 1.66 \\ \text { Leu } & 2.38 \pm 0.01 & 1.63 \pm 0.28 & 2.01 \\ \text { Lys } & 0.45 \pm 0.09 & 0.36 \pm 0.00 & 0.41 \\ \text { Met } & 17.37 \pm 1.20 & 13.93 \pm 0.23 & 15.65 \\ \text { Phe } & 6.31 \pm 0.38 & 2.89 \pm 0.02 & 4.60 \\ \text { Thr } & 2.64 \pm 0.31 & 1.30 \pm 0.02 & 1.97 \\ \text { Trp } & 5.88 \pm 0.47 & 2.23 \pm 0.03 & 4.06 \\ \text { Val } & 12.10 \pm 1.14 & 10.89 \pm 0.14 & 11.50\end{array}$

Non-essential amino acids

\begin{tabular}{lrcr} 
AAAA & $3.52 \pm 0.13$ & $6.45 \pm 0.14$ & 4.99 \\
Aaba & $0.33 \pm 0.03$ & $0.07 \pm 0.00$ & 0.20 \\
$\beta$-ala & $1.29 \pm 0.07$ & $0.97 \pm 0.00$ & 1.13 \\
Ala & $4.23 \pm 0.43$ & $4.32 \pm 0.05$ & 4.28 \\
Arg & $40.75 \pm 4.11$ & $31.64 \pm 0.45$ & 36.20 \\
Asn* & $73.35 \pm 5.13$ & $32.47 \pm 0.67$ & 52.91 \\
Asp & $91.69 \pm 7.32$ & $102.57 \pm 8.2$ & 97.13 \\
Citr & $0.42 \pm 0.05$ & $0.25 \pm 0.06$ & 0.34 \\
Cys & $0.76 \pm 0.04$ & $0.54 \pm 0.09$ & 0.65 \\
Cysth & $2.69 \pm 0.25$ & $0.13 \pm 0.19$ & 1.41 \\
Ethan & $2.74 \pm 0.09$ & $2.31 \pm 0.18$ & 2.53 \\
GABA & $0.26 \pm 0.04$ & $0.42 \pm 0.05$ & 0.34 \\
Gln* & $142.27 \pm 7.76$ & $70.22 \pm 0.95$ & 106.25 \\
Glu & $14.91 \pm 1.36$ & $17.83 \pm 0.20$ & 16.37 \\
Gly & $1.75 \pm 0.23$ & $2.30 \pm 0.01$ & 2.03 \\
Pea & $0.77 \pm 0.03$ & $0.54 \pm 0.13$ & 0.66 \\
Phser & $1.39 \pm 0.06$ & $1.22 \pm 0.18$ & 1.31 \\
Pro & $2.94 \pm 0.52$ & $2.12 \pm 0.11$ & 2.53 \\
Sarc & $5.65 \pm 0.26$ & $2.99 \pm 0.01$ & 4.32 \\
Ser & $2.08 \pm 0.31$ & $1.35 \pm 0.08$ & 1.72 \\
Taur & $0.91 \pm 0.41$ & $1.42 \pm 0.07$ & 1.17 \\
Tyr & $0.57 \pm 0.08$ & $0.83 \pm 0.06$ & 0.70 \\
Total & 453.95 & 322.42 & 388.39 \\
\hline & & & \\
\hline
\end{tabular}

Protein amino acids are reported in bold. Values are means $( \pm \mathrm{SD})$ of triplicate analyses $(n=3)$ and are expressed on a dryweight basis.

Data in the same row are not significantly different $(P>0.05)$ using the Bonferroni post-test.

*Very highly significant $(P<0.001)$. beans contain relatively high levels of monounsaturated fatty acids $(106 \mathrm{mg} / 100 \mathrm{~g} ; 8.8 \%$ of total fatty acids content). The most abundant monounsaturated acid is oleic acid (C18:1, n-9), representing $8.1 \%$ of the total fatty acid content $(98.03 \mathrm{mg} / 100 \mathrm{~g})$, a higher percentage than those of Češnjevec, Semenarna_22 and Cipro beans $(5.8 \%, 7.2 \%$ and $4.5 \%$, respectively). Furthermore, the gondoic acid (C20:1, n-9) content of 'Gallo Matese' beans was $1.33 \mathrm{mg} / 100 \mathrm{~g}$, whereas no traces of gondoic acid were detected in the three Slovenian bean varieties. Moreover, 'Gallo Matese' beans are an important source of essential polyunsaturated fatty acids, accounting for $71.5 \%$ of the total $(864 \mathrm{mg} / 100 \mathrm{~g})$. The principal polyunsaturated fatty acid in 'Gallo Matese' beans was $\alpha$-linolenic acid (C18:3, n-3; 476.35 $\mathrm{mg} / 100 \mathrm{~g}$ ), which represents about $40 \%$ of the total fatty acid content, a value about $40 \%$ lower than those of the three Slovenian bean varieties. Polyunsaturated linoleic acid (C18:2, n-6; $388.23 \mathrm{mg} / 100 \mathrm{~g})$ represents about $32 \%$ of total fatty acid content in 'Gallo Matese' beans, which is about $2.5 \%$ lower than Češnjevec beans and about $33 \%$ or $9 \%$ higher than Semenarna 22 or Cipro beans, respectively.

Finally, the balanced n-6 to n-3 ratio of $1: 1$ in ' Gallo Matese' beans ensures a good intake of polyunsaturated fatty acids, which are important for health and for the prevention and management of obesity (Simopoulos, 2016).

\section{Anti-proteinase inhibitor activity}

In general, beans contain several antinutritional compounds (ANCs), such as organic molecules or proteins (enzymes or protein inhibitors), whose assimilation has adverse effects on human health. Many of these ANCs are phytates, saponins, alkaloids, tannins, glycosides complex, lectins and proteinase inhibitors that interfere with the digestive processes (Krupa, 2008). In particular, protease inhibitors negatively affect the hydrolytic activities of proteases in protein intake, as a consequence of inhibition of proteolytic enzymes like trypsin and chymotrypsin (Sathe, 2012). Indeed, processes such as cooking or germination render these inhibitors inactivate, improving protein quality and increasing amino acid availability. In this framework, anti-trypsin and anti-chymotrypsin assays were carried out on a protein extract $(106.8 \mathrm{mg} / \mathrm{g}$ of seeds) obtained from 'Gallo Matese' beans collected from the $\mathrm{C} 1$ site 
Landi, N., Ragucci, S., Fiorentino, M., Guida, V., Di Maro, A. (2017). Nutritional values and metabolic profile with and without boiled treatment of 'Gallo Matese' beans (Phaseolus vulgaris L.), a landrace from Southern Italy. Acta Sci. Pol. Technol. Aliment., 16(3), 331-344. http://dx.doi.org/10.17306/J.AFS.2017.0510

Table 4. Fatty acid constituents of 'Gallo Matese' and Slovenian common beans (Pirman and Stibilj, 2003)

\begin{tabular}{|c|c|c|c|c|c|c|c|}
\hline \multirow{2}{*}{ Fatty acid } & \multicolumn{4}{|c|}{ 'Gallo Matese' beans, mg/100 g } & \multicolumn{3}{|c|}{ Slovenian common beans, $\mathrm{mg} / 100 \mathrm{~g}$} \\
\hline & $\mathrm{C}_{1}$ & $\mathrm{C}_{2}$ & $\overline{\mathrm{x}}$ & & Češnjevec & Semenarna 22 & Cipro \\
\hline \multicolumn{8}{|c|}{ Saturated fatty acids } \\
\hline Myristic & $14: 0$ & $1.79 \pm 0.30$ & $1.83 \pm 0.26$ & 1.81 & 0.80 & 1.60 & 2.20 \\
\hline Pentadecylic & $15: 0$ & $1.95 \pm 0.29$ & $1.90 \pm 0.19$ & 1.93 & 1.00 & 0.40 & 1.10 \\
\hline Palmitic & $16: 0$ & $196.94 \pm 9.70$ & $180.90 \pm 9.42$ & 188.92 & 201.00 & 181.00 & 233.00 \\
\hline Margaric & $17: 0$ & $2.46 \pm 0.47$ & $2.65 \pm 0.48$ & 2.54 & 2.70 & 3.10 & 3.10 \\
\hline Stearic & $18: 0$ & $31.70 \pm 2.26$ & $32.84 \pm 2.30$ & 32.27 & 24.40 & 17.10 & 22.10 \\
\hline Arachidic & $20: 0$ & $5.00 \pm 0.50$ & $4.66 \pm 0.46$ & 4.83 & 4.40 & 1.50 & 3.90 \\
\hline \multirow[t]{2}{*}{ Behenic } & $22: 0$ & $5.46 \pm 0.59$ & $5.65 \pm 0.62$ & 5.56 & 3.50 & 10.60 & in trace \\
\hline & \multicolumn{3}{|r|}{ SFA, mg } & 238 & 238 & 215 & 266 \\
\hline \multicolumn{8}{|c|}{ Monounsaturated fatty acid } \\
\hline Palmitoleic & $16: 1, n-7$ & $5.89 \pm 0.63$ & $5.46 \pm 0.52$ & 5.68 & 3.60 & 3.10 & 3.20 \\
\hline Heptadecenoic & $17: 1, \mathrm{n}-7$ & $1.05 \pm 0.21$ & $1.37 \pm 0.26$ & 1.21 & 1.50 & 1.80 & 1.60 \\
\hline Oleic & $18: 1, n-9$ & $99.02 \pm 7.08$ & $97.04 \pm 6.69$ & 98.03 & 86.60 & 102.00 & 66.50 \\
\hline \multirow[t]{2}{*}{ Gondoic } & $20: 1, n-9$ & $1.40 \pm 0.37$ & $1.25 \pm 0.29$ & 1.33 & n.d. & n.d. & n.d. \\
\hline & \multicolumn{3}{|r|}{ MUFA, mg } & 106 & 92 & 107 & 71 \\
\hline \multicolumn{8}{|c|}{ Polyunsaturated fatty acid } \\
\hline Linoleic & $18: 2, \mathrm{n}-6$ & $393.26 \pm 12.61$ & $383.19 \pm 11.50$ & 388.23 & 398.00 & 261.00 & 354.00 \\
\hline \multirow[t]{3}{*}{ a-Linolenic } & $18: 3, \mathrm{n}-3$ & $470.42 \pm 13.97$ & $482.28 \pm 12.54$ & 476.35 & 761.00 & 825.00 & 781.00 \\
\hline & \multicolumn{3}{|r|}{ PUFA } & 864 & 1159 & 1086 & 1135 \\
\hline & \multicolumn{3}{|r|}{ Total FA, g } & 1.21 & 1.49 & 1.41 & 1.47 \\
\hline
\end{tabular}

Values are means $( \pm \mathrm{SD})$ of triplicate analyses $(n=3)$ and are expressed on a dry-weight basis.

Data in the same row are not significantly different $(P>0.05)$ using a Bonferroni post-test.

n.d. - not determined.

and available in larger quantities for this biochemical characterization with and without boiling process. The inhibitory activity obtained from the protein extract (Fig. 2) was reported as $\mathrm{IC}_{50}$ value. The anti-chymotrypsin activity of 'Gallo Matese' beans without thermal treatment ( $\mathrm{IC}_{50} 1.65 \mathrm{mg}$ of raw protein extract) was $\sim 26 \%$ higher than the anti-trypsin activity $\left(\mathrm{IC}_{50} 2.21\right.$ $\mathrm{mg}$ of raw protein extract), while no protease activities were detected in the same experimental conditions. On the other hand, to confirm the decreasing effect of the boiling process on trypsin inhibitor content, aliquots of 'Gallo Matese' seeds were boiled for 60 and $120 \mathrm{~min}$, respectively, and their anti-protease activities were reassayed. The protein extract from seeds after 60 and $120 \mathrm{~min}$ of boiling process showed a protein concentration of 3.20 and $2.00 \mathrm{mg} / \mathrm{g}$ of seeds, respectively. After a thermal treatment of $60 \mathrm{~min}$, these results indicated that anti-chymotrypsin, as well as anti-trypsin activities were $\sim 81 \%\left(\mathrm{IC}_{50} 8.70 \mathrm{mg}\right.$ of raw protein extract) and $\sim 76 \%$ ( IC $_{50} 9.40 \mathrm{mg}$ of raw protein extract) 

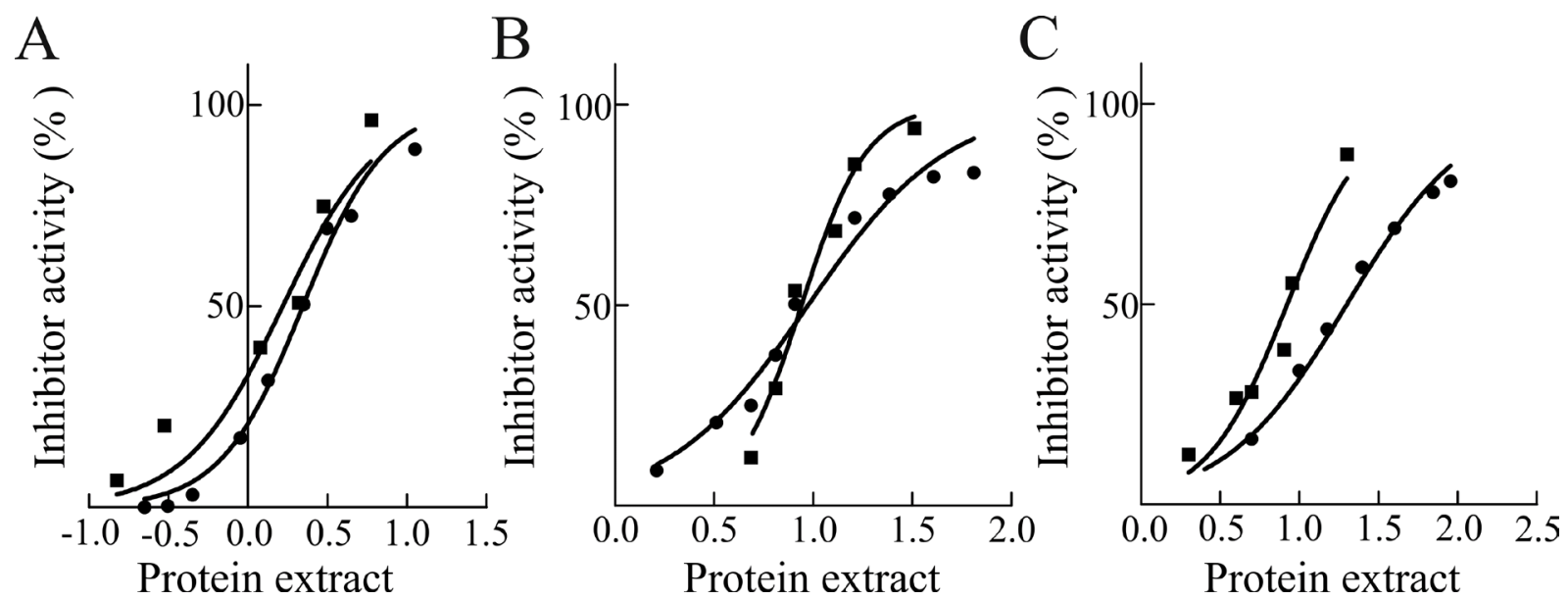

Fig. 2. Inhibition curves of trypsin (•) and $\alpha$-chymotrypsin ( $\bullet$ ) by raw protein extract obtained from raw beans (A) or cooked beans at 1 hour (B) or 2 hour (C), respectively. Increasing concentrations of raw protein extract were added to a fixed concentration of enzymes as indicated in Material and methods

lower than those detected in raw bean seeds, respectively. On the other hand, anti-chymotrypsin and also anti-trypsin activities after $120 \mathrm{~min}$ were $\sim 80 \%\left(\mathrm{IC}_{50}\right.$ $8.40 \mathrm{mg}$ of raw protein extract) and $\sim 89 \%\left(\mathrm{IC}_{50} 20.00\right.$ $\mathrm{mg}$ of raw protein extract) lower than those detected in raw bean seeds, respectively. Therefore, as previously reported for other legumes, the boiling process reduces the anti-protease activities of 'Gallo Matese' beans. In addition, the thermal treatment has a higher effect on anti-trypsin with respect to anti-chymotrypsin activities. Therefore, this finding highlights the fact that boiled beans have a residual heat-resistant antichymotrypsin and anti-trypsin activity involved in the anti-cancer properties of legumes, due to carcinogenesis suppression, inhibiting proteolytic activities and/ or expression of some proto-oncogenes as reported for colorectal cancer (Clemente and Arques, 2014; Lima et al., 2016).

\section{Total phenol content and antioxidant capability of raw and boiled 'Gallo Matese' beans}

Several epidemiological and clinical studies report the benefits of consuming legumes such as common beans due to the presence of phenolic compounds (Pauwels, 2011). Indeed, since polyphenols act as hydrogen donators, singlet oxygen quenchers or chelators, they are considered antioxidant agents (Zhang, 2015). Hence, we have determined the total polyphenol content
(TPC) from 'Gallo Matese' beans collected from C1 site available in larger quantities for this biochemical characterization, extracted by using a rotary shaker and acetone/water as extractants. The calculated TPC value was compared with that of beans previously boiled in water for $2 \mathrm{~h}$, as occurs in the Mediterranean culinary tradition (see Methods). The polyphenol content of the boiling water was also measured. The TPC value of raw beans, $216.76 \mathrm{mg}$ GAE per $100 \mathrm{~g}$, was slightly higher than that of cooked beans (193.64 mg GAE per $100 \mathrm{~g}$ ), whereas a poor amount of phenol substances was released in boiling water samples (15.76 mg GAE per 100 g; Fig. 3A). Thus, the effect of conventional boiling treatment seemed to have a weak influence on the 'Gallo Matese' beans' polyphenol content at atmospheric pressure. The variation of TCP is in agreement with previous studies, which found that boiling thermal treatment decreased the total phenolic content in vegetables due to the leaching of phenolic compounds into the cooking water, as well as the breakdown of these compounds during processing (Ismail et al., 2004; Xu and Chang, 2008). Interestingly, the lyophilized extract of cooked beans together with their cooking water displays a slight increase in the TPC, $276.16 \mathrm{mg}$ GAE per $100 \mathrm{~g}$ (Fig. 3A).

The TPC of raw 'Gallo Matese' beans has also been compared in similar studies on different Italian Phaseolus vulgaris seeds by using the Folin-Ciocalteu 

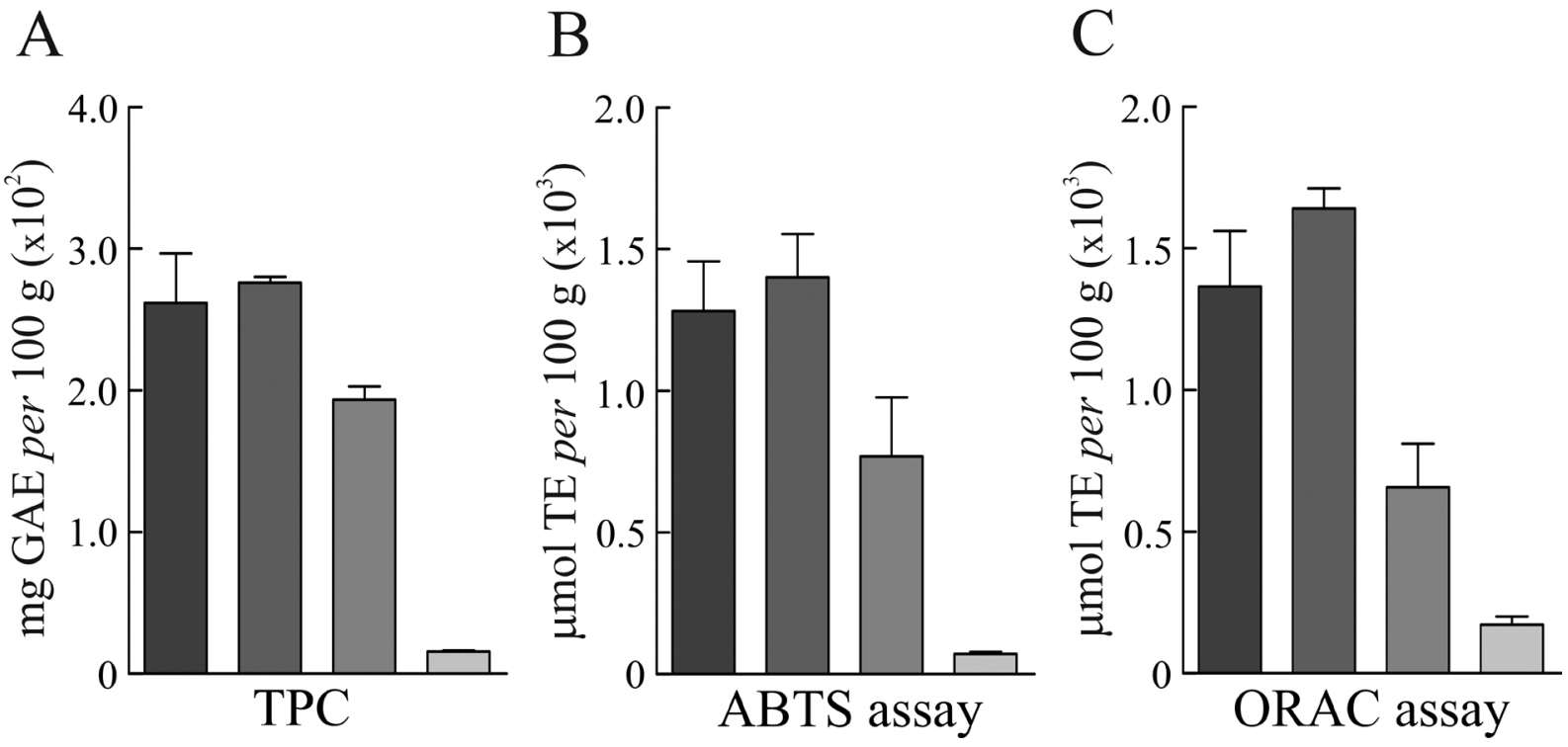

Fig. 3. Total phenol content and antioxidant capabilities in both raw beans, cooked beans with and without cooking waters and cooking water: A - total phenol content (TPC) method data, B - ABTS method data, C - ORAC method data. TPC are expressed as mg of gallic acid equivalents (GAE); ORAC and ABTS are expressed as $\mu$ mol of trolox equivalents (TE) per $100 \mathrm{~g}$ on a dry-weight basis of each sample $\pm \mathrm{SD}$

method. It was observed that the TPC content of 'Gallo Matese' beans is lower with respect to 'Fagiolo occhio nero di Oliveto Citra' [310 mg GAE per $100 \mathrm{~g}$ (Zaccardelli et al., 2013)] seeds, but it is within the range 135-275 mg GAE per $100 \mathrm{~g}$, as previously reported for other Italian white landraces (Ombra et al., 2016).

The evaluation of the antioxidant capability of the three extracts (raw seeds, cooked seeds with or without cooking water and cooking water) from 'Gallo Matese' beans was carried out by performing ABTS and ORAC methods. The data reveal that boiling treatment decreased 'Gallo Matese' beans' free radical scavenging efficacy (Fig. 3B, 3C). Interestingly, in this case the lyophilized extract of cooked beans together with their cooking water displays a slight increase in antioxidant capability. This increase is probably due to the cooking process, which could cause the thermal degradation of phytochemicals, but also the increase in antioxidant total content by enhancing their availability for extraction through the inactivation of polyphenol oxidase, or the release of fiber-bound polyphenols into free polyphenols (Miglio et al., 2008).

\section{CONCLUSIONS}

Despite 'Gallo Matese' bean seeds having been consumed for centuries, there is still little information about their nutritional value. Today, interest in cultivation of this variety has increased because of healthconscious consumers becoming increasingly careful when choosing alternative healthy diets such as the Mediterranean diet.

Data obtained from our analysis emphasized that 'Gallo Matese' beans are a functional food, confirming that these seeds are rich in raw proteins and carbohydrates, and poor in lipids, mainly composed of unsaturated fatty acids. This finding provides additional information about both total and free amino acids, and total phenol content. Most importantly, the present work suggests radical scavenging activity, observed 
even after the boiling process and partially in boiling water. This result confirms the healthy Italian habit of cooking pasta e fagioli in boiling water, preserving most of the radical scavenging activity. In contrast the process of boiling beans reduces proteinase inhibitors, such as anti-trypsin and anti-chymotrypsin, which interfere with digestive processes. On the other hand, beans that have undergone boiling treatment have residual heat-resistant anti-trypsin and anti-chymotrypsin activity, which is likely to be involved in the anti-cancer properties of legumes.

Overall, these results are useful for promoting the cultivation of 'Gallo Matese' beans and their consumption, due to their healthy food qualities. Furthermore, these data lay the basis for long-term agronomic experiments aimed at defining the goodness of this species compared to a standard species cultivated in the same area.

\section{ACKNOWLEDGEMENTS}

The authors are grateful to the people of Gallo Matese and, in particular, to Giovanni Antonio Palumbo (Mayor of the town).

\section{REFERENCES}

Amarowicz, R., Pegg, R. B. (2008). Legumes as a source of natural antioxidants. Eur. J. Lipid Sci. Technol., 110(10), 865-878. https://doi.org/10.1002/ejlt.200800114

Anton, A. A., Gary Fulcher, R., Arntfield, S. D. (2009). Physical and nutritional impact of fortification of corn starch-based extruded snacks with common bean (Phaseolus vulgaris L.) flour: Effects of bean addition and extrusion cooking. Food Chem., 113(4), 989-996. https://doi.org/10.1016/j.foodchem.2008.08.050

AOAC. (1997). Official methods of analysis. Arlington, VA, USA: The Association of Official Analytical Chemests.

Azarpazhooh, E., Boye, J. I. (2012). Composition of processed dry beans and pulses. Dry beans and pulses production, processing and nutrition (pp. 101-128). Blackwell Publ. https://doi.org/10.1002/9781118448298.ch5

Bailly, C., Audigier, C., Ladonne, F., Wagner, M. H., Coste, F., Corbineau, F., Come, D. (2001). Changes in oligosaccharide content and antioxidant enzyme activities in developing bean seeds as related to acquisition of drying tolerance and seed quality. J. Exp. Bot., 52(357), 701708. https://doi.org/10.1093/jexbot/52.357.701
Bazzano, L. A., He, J., Ogden, L. G., Loria, C., Vupputuri, S., Myers, L., Whelton, P. K. (2001). Legume consumption and risk of coronary heart disease in US men and women: NHANES I Epidemiologic Follow-up Study. Arch. Intern. Med., 161(21), 2573-2578. https://doi. org/10.1001/archinte.161.21.2573

Clemente, A., Arques, M. D. C. (2014). Bowman-Birk inhibitors from legumes as colorectal chemopreventive agents. World J. Gastroenterol., 20(30), 10305-10315. https://doi.org/10.2174/138920311796391133

Comes, O. (1910). Del fagiolo comune: storia, filogenesi, qualità sospettata tossicità e sistemazione delle sue razze ovunque coltivate. Atti Ist. Incoragg. Napoli, 61, 75-145.

CREA. (2009). Centro di Ricerca per gli Alimenti e la Nutrizione. Available at: http://nut.entecra.it/

Del Piano, L., Capone, C., Abet, M., Sorrentino, C., Sicignano, M., Enotrio, T. (2012). ISSR and SSR analysis of Italian common bean 'Controne' ecotypes. Acta Horticulturae, 191-198. https://doi.org/10.17660/ ActaHortic.2012.929.27

Dosi, R., Daniele, A., Guida, V., Ferrara, L., Severino, V., Di Maro, A. (2013). Nutritional and metabolic profiling of the globe artichoke (Cynara scolymus L. cv. capuanella heads) in province of Caserta, Italy. Aust. J. Crop Sci., 7(12), 1927-1934

FAO. (2003). Food energy - Methods of analysis and conversion factors. Report of a Technical Workshop. 3-6 December 2002. FAO Food and Nutrition Paper no. 77. Rome.

Ferrara, L., Dosi, R., Di Maro, A., Guida, V., Cefarelli, G., Pacifico, S., ..., Parente, A. (2011). Nutritional values, metabolic profile and radical scavenging capacities of wild asparagus (A. acutifolius L.). J. Food Comp. Anal., 24, 326-333. https://doi.org/10.1016/j.jfca.2010.10.008

Gazzetta_Ufficiale. (2016). Decreto Ministeriale 23 maggio 2016 - G.U. n. 143 del 21.06.2016 (pp. 54-61). Gazzetta Ufficiale (G.U.) della Repubblica Italiana.

Iqbal, A., Khalil, I. A., Ateeq, N., Sayyar Khan, M. (2006). Nutritional quality of important food legumes. Food Chem., 97(2), 331-335. http://dx.doi.org/10.1016/j. foodchem.2005.05.011

Iriti, M., Di Maro, A., Bernasconi, S., Burlini, N., Simonetti, P., Picchi, V., ..., Faoro, F. (2009). Nutritional traits of bean (Phaseolus vulgaris) seeds from plants chronically exposed to ozone pollution. J. Agric. Food Chem., 57(1), 201-208. https://doi.org/10.1021/jf802819m

Ismail, A., Marjan, Z. M., Foong, C. W. (2004). Total antioxidant activity and phenolic content in selected 
Landi, N., Ragucci, S., Fiorentino, M., Guida, V., Di Maro, A. (2017). Nutritional values and metabolic profile with and without boiled treatment of 'Gallo Matese' beans (Phaseolus vulgaris L.), a landrace from Southern Italy. Acta Sci. Pol. Technol. Aliment., 16(3), 331-344. http://dx.doi.org/10.17306/J.AFS.2017.0510

vegetables. Food Chem., 87(4), 581-586. https://doi. org/10.1016/j.foodchem.2004.01.010

Jenkins, D. J., Kendall, C. W., Augustin, L. S., Mitchell, S., Sahye-Pudaruth, S., Blanco Mejia, S., ..., Josse, R. G. (2012). Effect of legumes as part of a low glycemic index diet on glycemic control and cardiovascular risk factors in type 2 diabetes mellitus: a randomized controlled trial. Arch. Intern. Med., 172(21), 1653-1660. https:// doi.org/10.1001/2013.jamainternmed.70

Katungi, E., Farrow, A., Chianu, J., Sperling, L., Beebe, S. (2009). Common bean in Eastern and Southern Africa: A situation and outlook analysis. Intern. Centre Tropic. Agric., 61, 1-26.

Krupa, U. (2008). Main nutritional and antinutritional compounds of bean seeds - a review. Pol. J. Food Nutr. Sci., 58(2), 149-155.

Landi, N., Pacifico, S., Piccolella, S., Di Giuseppe, A. M. A., Mezzacapo, M. C., Ragucci, S., ..., Di Maro, A. (2015). Valle Agricola lentil, an unknown lentil (Lens culinaris Medik.) seed from Southern Italy as a novel antioxidant and prebiotic source. Food Funct., 6(9), 3155-3164. https://doi.org/10.1039/c5fo00604j

Landi, N., Pacifico, S., Ragucci, S., Di Giuseppe, A. M. A., Iannuzzi, F., Zarrelli, A., ..., Di Maro, A. (2017). Pioppino mushroom in the Southern Italy: an undervalued source of nutrients and bioactive compounds. J. Sci. Food Agric. https://doi.org/10.1002/jsfa.8428

Lee, S. J. (1982). Aspects of European history, 1789-1980. Routledge.

Lima, A. I., Mota, J., Monteiro, S. A., Ferreira, R. M. (2016). Legume seeds and colorectal cancer revisited: Protease inhibitors reduce MMP-9 activity and colon cancer cell migration. Food Chem., 197(Pt A), 30-38. https://doi. org/10.1016/j.foodchem.2015.10.063

Mennella, G., Onofaro Sanajà, V., D'Alessandro, A., Milone, M., Perrone, D. (2003). HPLC analyses of seed storage proteins reveal polymorphism in Italian common bean (Phaseolus vulgaris L.) ecotypes. Euphytica, 134(1), 85-95. https://doi.org/10.1023/A:1026127004224

Miglio, C., Chiavaro, E., Visconti, A., Fogliano, V., Pellegrini, N. (2008). Effects of different cooking methods on nutritional and physicochemical characteristics of selected vegetables. J. Agric. Food Chem., 56(1), 139 147. http://dx.doi.org/10.1021/jf072304b

Mudryj, A. N., Yu, N., Aukema, H. M. (2014). Nutritional and health benefits of pulses. Appl. Physiol. Nutr. Metab., 39(11), 1197-1204. https://doi.org/10.1139/ apnm-2013-0557

Neacsu, M., McBey, D., Johnstone, A. M. (2016). Meat reduction and plant-based food: Replacement of meat: nutritional, health, and social aspects. In: S. Nadathur, J. P. D. Wanasundara, L. Scanlin (Eds.), Sustainable protein sources (pp. 359 -376). London, United Kingdom: Elsevier Science.

Nedumaran, S., Abinaya, P., Jyosthnaa, B., Shraavya, B., Rao, P. C. B. (2015). Grain legumes production, consumption and trade trends in developing countries (ICRISAT). Telangana, India. Int. Crops Res. Inst. SemiArid Tropics, 64. https://doi.org/10.21421/D2/BTUT4Y

Nelson, M. E., Hamm, M. W., Hu, F. B., Abrams, S. A., Griffin, T. S. (2016). Alignment of healthy dietary patterns and environmental sustainability: A systematic review. Adv. Nutr., 7(6), 1005-1025. https://doi.org/10.3945/ an.116.012567

Nulik, J., Dalgliesh, N., Cox, K., Gabb, S. (2013). Integrating herbaceous legumes into crop and livestock systems in eastern Indonesia. Australian Centre for International Agricultural Research (ACIAR).

Ombra, M. N., D’Acierno, A., Nazzaro, F., Riccardi, R., Spigno, P., Zaccardelli, M., ..., Fratianni, F. (2016). Phenolic composition and antioxidant and antiproliferative activities of the extracts of twelve common bean (Phaseolus vulgaris L.) endemic ecotypes of southern Italy before and after cooking. Oxid. Med. Cell Longev. https:// doi.org/10.1155/2016/1398298

Oomah, B. D., Patras, A., Rawson, A., Singh, N., ComposVega, R. (2011). 2 - Chemistry of pulses A2 - Tiwari, Brijesh K. In: A. Gowen, B. McKenna (Eds.), Pulse foods (pp. 9-55). San Diego: Academic Press. http://doi. org/10.1016/B978-0-12-382018-1.00002-2

Pacifico, S., Di Maro, A., Petriccione, M., Galasso, S., Piccolella, S., Di Giuseppe, A. M. A., ..., Monaco, P. (2014). Chemical composition, nutritional value and antioxidant properties of autochthonous Prunus avium cultivars from Campania Region. Food Res. Int., 64, 188-199. http://dx.doi.org/10.1016/j.foodres.2014.06.020

Pauwels, E. K. (2011). The protective effect of the Mediterranean diet: focus on cancer and cardiovascular risk. Med. Princ. Pract., 20(2), 103-111. https://doi. org/10.1159/000321197

Piergiovanni, A. R., Lioi, L. (2010). Italian common bean landraces: History, genetic diversity and seed quality. Diversity, 2(6), 837-862. https://doi.org/10.3390/ d2060837

Piergiovanni, A. R., Villecco, D., Lioi, L., Zaccardelli, M. (2015). Comparison among recognized and non-recognized Phaseolus vulgaris L. landraces as traditional agro-food products of the Campania region (Italy). Genet. Resour. Crop Evol., 62(7), 1009-1019. https://doi. org/10.1007/s10722-014-0204-4 
Pirman, T., Stibilj, V. (2003). An influence of cooking on fatty acid composition in three varieties of common beans and in lentil. Eur. Food Res. Technol., 217(6), 498-503. https://doi.org/10.1007/s00217-003-0784-2

Postles, J., Curtis, T. Y., Powers, S. J., Elmore, J. S., Mottram, D. S., Halford, N. G. (2016). Changes in free amino acid concentration in rye grain in response to nitrogen and sulfur availability, and expression analysis of genes involved in asparagine metabolism. Front. Plant Sci., 7(917). https://doi.org/10.3389/fpls.2016.00917

Sathe, S. K. (2012). Chemistry and implications of antinutritional factors in dry beans and pulses. In: M. Siddiq, M. A. Uebersax (Eds.), Dry beans and pulses production, processing and nutrition (pp. 359-377). John Wiley. https://doi.org/10.1002/9781118448298.ch15

Scarano, D., Rubio, F., Ruiz, J. J., Rao, R., Corrado, G. (2014). Morphological and genetic diversity among and within common bean (Phaseolus vulgaris L.) landraces from the Campania region (Southern Italy). Sci. Hortic., 180, 72-78. https://doi.org/10.1016/j. scienta.2014.10.013

Simopoulos, A. P. (2016). An increase in the omega-6/ omega-3 fatty acid ratio increases the risk for obesity. Nutrients, 8(3), 128. https://doi.org/10.3390/nu8030128

Tamburino, R., Guida, V., Pacifico, S., Rocco, M., Zarelli, A., Parente, A., Di Maro, A. (2012a). Nutritional values and radical scavenging capacities of grass pea (Lathyrus sativus L.) seeds in Valle Agricola district, Italy. Aust. J. Crop. Sci., 6, 149-156.
Tamburino, R., Severino, V., Sandomenico, A., Ruvo, M., Parente, A., Chambery, A., Di Maro, A. (2012b). De novo sequencing and characterization of a novel Bowman-Birk inhibitor from Lathyrus sativus L. seeds by electrospray mass spectrometry. Mol. Biosyst., 8(12), 3232-3241. https://doi.org/10.1039/c2mb25241d

Widmer, R. J., Flammer, A. J., Lerman, L. O., Lerman, A. (2015). The Mediterranean diet, its components, and cardiovascular disease. Am. J. Med., 128(3), 229-238. https://doi.org/10.1016/j.amjmed.2014.10.014

Xu, B. J., Chang, S. K. C. (2008). Total phenolic content and antioxidant properties of eclipse black beans (Phaseolus vulgaris L.) as affected by processing methods. J. Food Sci., 73(2), H19-H27. https://doi. org/10.1111/j.1750-3841.2007.00625.x

Zaccardelli, M., Pentangelo, A., Tripodi, P. (2013). Characterization of bean (Phaseolus vulgaris L.) ecotype "Fagiolo occhio nero di Oliveto Citra" using agronomic, biochemical and molecular approaches. Pak. J. Biol. Sci., 16(18), 901-910. https://doi.org/10.3923/ pjbs.2013.901.910

Zeven, A. C. (1997). The introduction of the common bean (Phaseolus vulgaris L) into Western Europe and the phenotypic variation of dry beans collected in the Netherlands in 1946. Euphytica, 94(3), 319-328. https://doi. org/10.1023/a:1002940220241

Zhang, P. Y. (2015). Polyphenols in Health and Disease. Cell Biochem. Biophys., 73(3), 649-664. https://doi. org/10.1007/s12013-015-0558-Z 